\title{
An Exploratory Study of Perceptions of Hotel Working Conditions on the Promotion Decision
}

\author{
Candace Blayney, Associate Professor (Corresponding Author) \\ Mount Saint Vincent University \\ 166 Bedford Highway \\ Halifax, Nova Scotia \\ B3M 2J6
}

\author{
Karen Blotnicky, Professor \\ Mount Saint Vincent University
}

Sarita Singh, Alumni

Mount Saint Vincent University

Received: Apr. 26, 2021 Accepted: May. 26, 2021 Online published: Jun. 6, 2021

doi:10.5296/ijhrs.v11i2.18565 URL: https://doi.org/10.5296/ijhrs.v11i2.18565

\begin{abstract}
This exploratory paper focuses on identifying the working conditions that may impact an employee's decision to apply for a promotion in the pursuit of a management position in the hotel industry in Canada and possibly moving up to that of executive position of hotel general manager. A survey sent to a sample of hotel employees in a mid-sized Atlantic Canada city addressed 21 working conditions that may impact employees when considering applying for a promotion. Findings include the working condition with the greatest impact was "having the empowerment to make changes". The one with the least impact was "having to work overtime". These findings would assist management to understand the factors that may motivate employees to pursue job promotions and fill the current talent gap. Significant differences were noted for the impact of some of the working conditions on the promotion decision based on age, gender, education, marital status, and level of position within the firm.
\end{abstract}

Keywords: working conditions, career advancement, gender, hotel management 


\section{Introduction}

\subsection{Growth of the Industry}

The hospitality industry strives to be competitive to attract new employees. A global hospitality labor shortage is forecasted even with the impact of the COVID-19 pandemic, and the lack of qualified employees for the hospitality industry as an estimate, could cost the global economy "approximately 14 million jobs and nearly US\$60 billion in GDP" (WTTC, 2015a). When travel becomes safe again, this talent shortage will reoccur and will impact any hotel organization's growth plans. In the face of future increased tourism growth on an international level, hotel companies need to remain competitive by having product supply available in tourism destinations. The tourism industry has "contributed nearly $\$ 7$ billion to the global economy in 2014, which is forecast to rise to $\$ 11$ trillion by 2024 " (WTTC, 2015b). In Canada there is a direct impact of the labor shortage on organizational slow growth. Companies experiencing worker shortages are $65 \%$ more likely to be a low-growth company (Cocolakis-Wormstall, 2018). So, there is much at stake that depends on the human talent of a hotel not only at the front-line level, but at the middle and upper management levels that steer the company strategically towards its future. In the future as the tourism industry rebounds, the labor shortage will increase. The domestic labor supply is forecasted to remain level, and this could result in an erosion of a country's tourism base due to the lack of supply and services in this industry (WTTC, 2015b).

\subsection{Working Conditions and Career Pathways}

The hotel industry is known for its demanding working conditions such as operating hours of 24 hours a day, seven days and week and 365 days a year, fluctuating demand patterns, high customer contact environments and the looming work force shortage (Ghebregiorgis, 2018; Swe \& Walsh, 2016). Careers of managers in the hotel industry have been examined to determine pathways but little research exists on the reasons why hotel employees apply or do not apply for promotions (Harper, Brown, \& Irvine, 2005; Kim, Chun, Petrick, 2009; Ladkin, 2002; Nebel III, Lee, \& Vidakovic, 1995; Obrien, 2014). The career pathway to the position of hotel manager mainly progresses in a linear fashion such as discussed by Morgan (2002) who created the Holistic Career Pyramid Model. In this model the building blocks to reach the executive position consist of expertise in four areas: technical, aptitude, initiative and relational. An employee working and moving from front-line position to supervisor and then to management would develop these areas of expertise. Kim, Chun, \& Petrick (2009) also noted the vertical rise of hotel general managers in Korea as they spent time in the food and beverage division, sales and marketing division and room division on their way to becoming the General Manager of a super deluxe hotel.

There are also positions beyond that of hotel general manager in large hotel companies. Regional positions exist such as Regional Vice President of Operations in large international hotel organizations such as InterContinental Hotel Group or Marriott Hotels and Resorts. The first step in the career ladder is from one of on-line employee to supervisor, then to assistant department manager, to department managers and so on. If the working conditions of long hours, high customer contact and dynamic business levels are so demanding, then what 
makes people wish to work in this environment and what propels them forward? A further understanding of what drives managers to repeatedly ask for jobs with more responsibility will allow human resource managers to better understand and implement career strategies to assist those who wish to attain higher positions within the industry.

This research explores the perceived working conditions that are considered to have an impact on the decision to apply for a promotion in the hotel industry. This paper discusses the hotel industry and various career strategies and theories used. The methodology and the results are described, followed by a discussion of the findings. The paper ends with a conclusion and recommendations for future research.

\section{Literature Review}

\subsection{The Hotel Industry}

The position of hotel general manager is equal to that of CEO of the hotel property. They have direct impact on all divisions and all levels in the property including finance, human resources, regulations, and budgeting (Akrivos, Ladkin, \& Reklitis, 2007). A hotel general manager can impact the failure or success of the business. The pathway to achieve an executive position in a hotel from entry level to general manager can vary but it is usually linear in fashion. Certain positions in a hotel are major career steppingstones while some others are not. Early research in 1995 (Nebel, Lee \& Vidakovic) found 45\% of hotel managers in the USA worked in food and beverage and $30 \%$ in the rooms division before becoming hotel general managers. The most popular route is via those positions in food and beverage and rooms management due to the requirements and complexity of the jobs. It averages 14.1 years to reach the position of hotel general manager (Ladkin, 2002) and frequent moves from property to property are encouraged to gain deeper and broader business environment experiences (Blayney \& Blotnicky, 2014).

There are several barriers to applying for job promotions in the hotel industry and they are primarily due to working conditions. The industry involves delivering an intangible hospitality product called service, which is critical to the guest experience, with the goal of turning a guest into the highly valued frequent customer. Relationships are formed between the hospitality employees and the guests which greatly influences customer satisfaction and loyalty. This high customer contact with various types of travelers who all have their unique demands can be stressful for those individuals serving them.

The industry also operates in a 24-hour, 7 day a week and 365 days a year mode, unless it is a seasonal resort. This can encompass long hours, irregular shift work, fast paced environments, and high levels of guest interactions (U.S. Bureau of Labor Statistics, 2018). For some people this can be extremely tiring and for others it is energizing. The hotel industry is attractive to those who function well in high energy, demanding, and fast paced environments. Yildirim, Gulmez \& Yildirim (2016) found in their research on the five-factor personality traits that the Extraversion and Openness dimension has a positive effect on job satisfaction. Brown (2011) found employees enjoyed the excitement of the industry and those that stayed in the industry enjoyed "being challenged and having new experiences" (p. 78). Research on 
hotel managers conducted by Blayney \& Blotnicky (2014) revealed that major barriers to advancement in one's career were personality, opportunity/timing, and willingness to move. This research also noted that the major facilitators to career advancement were learning/education followed by hard work and personality (Blayney \& Blotnicky, 2014). Ruddy (1989) in an earlier study also found that personal characteristics were most influential on hotel managers' career development and included those with a high need to achieve, are prepared to work with others, and seek opportunities and take risks. Swanljung (1981) found energy, hard work, fairness, the ability to motivate, having good judgement, and a positive and outgoing personality were major success factors for hotel managers. These findings stress the importance of having the right personality and character to be successful in this industry.

In research on the perceptions of the hospitality industry, those who never worked in the industry were surveyed and the findings noted that "the hotel industry pays well and offers chances for training, advancement, and career development" (McGinley, Hanks \& Line, 2017, p. 120). However, the nature of the hotel industry with its long operating hours was found to have a negative impact on the attitudes toward the job. This research also found that "the stability of one's home situation also plays a significant role in occupational choice" (McGinley et al, 2017, p. 121). The role of line managers was also found to be important on individuals' perceptions of the industry and career development. Those who felt they had support from their line managers were more positive in career development activities (Crawshaw \& Game, 2015).

\subsection{Career Advancement}

There is a wealth of research on the requirements to gain promotions within the hotel industry but there is little research on why employees choose to apply for a promotion in the hotel industry (Akrivos, Ladkin \& Reklitis, 2007; Blayney \& Blotnicky, 2016; Garavan, O’Brien \& O'Hanlon, 2006; Harper, Brown \& Irvine, 2005; Kim, Chun \& Petrick, 2009; Ladkin, 2002; Ladkin \& Juwaheer, 2000). Factors and/or strategies identified as essential to career success include: career history (as some positions such as in food and beverage lead to general manager and some do not); competencies such as guest relations; ability to increase profits; teambuilding; moving properties; being alert for promotion opportunities; and being hard-working (Kim, Chun \& Petrick, 2009).

Reasons for staying in the hospitality industry were explored by Brown (2011) who found that they "enjoyed working with people, enjoyed serving others, and enjoyed the excitement of hospitality" (p. 79-81). This may explain why one may stay in the industry, but they are not necessarily the reasons why one would apply for promotion to a job with more responsibility. This gap will be explored in this research.

Career anchor theory has been used to examine the careers of hospitality managers. Schein's career anchor theory is based on motivations, attitudes and values that guide a career and it has been used to predict individual career choices and response to career opportunities (Schein, 1975). There are eight anchors in Schein's theory including: Technical and Functional, General Management, Autonomy and Independence, Security and Stability, Entrepreneurial Creativity, Service and Dedication to a Cause, Pure Challenge and Life Style. 
The highest score indicates one's preferred career anchor: the environment in which they prefer to work. In research with hospitality managers in Scotland it was found that the dynamic nature of the hospitality industry is attractive to those managers with a "pure challenge career anchor" (McGuire, Polla \& Heidl, 2017). This pure challenge career anchor is a value-based career anchor for those who like to work on tough problems, and who like novelty, variety, and difficulty. Garavan, O'Brian \& O'Hanlon (2016) examined hotel general manager career anchors and found they have two major anchors including "a desire to manage people and an emphasis on service and dedication" (p. 580). This research will explore further some of these factors that may impact employees to apply or not to apply for a promotion.

Generational differences occur in motivations and career expectations. The "Boomer" generation born between 1946 and 1964, believe that working long hours results in job promotion and higher pay which are indicators of career success status and was a reward in itself. However, the Millennials, born between 1981 and 1996 (Dimock, 2019) appear to have different motivations. Higher pay and promotions may initially attract Millennials, but it does not lead to retention. Deloitte research (2019) found that they are attracted to flexibility in schedules and leisure time, and the ability to complete the work in their own manner. They wished to earn a high salary which was ranked second among ambitions and two thirds wanted to reach senior levels in their careers. Due to experiencing the economic upheavals and radical changes for the past decade Millennials may need to have this potential career success reinforced in their workplaces. But they believe that businesses should do more for the environment and only 37 percent "believe business leaders make a positive impact on the world" (Deloitte, 2019, p. 11). To attract, retain and motivate this generation to achieve higher level careers may be a challenge for most organizations. When asked who has the most responsibility for preparing workers for the industry Millennials "say business $(30 \%)$ has the greatest responsibility for preparing workers, followed by educational institutions (24\%)" (Deloitte, 2019, p. 13). It appears Millennials are looking for the organizations that they join to take on the responsibility of training and preparing them to succeed.

Promotions can be an extrinsic reward as well as intrinsic. Extrinsic motivation is from outside the individual such as monetary rewards or a bonus. Intrinsic rewards come from within the individual such as finding the job fun or wishing to be challenged (Putra, Cho \& Liu, 2017). Promotions may be a form of recognition, for performing well on the job and leading to higher pay. But promotions can also be intrinsic, leading to more challenges, greater decision-making situations, and changes in the working environment. Competitive salary and promotional opportunities were identified by hospitality managers as being the top two most important rewards (Walsh \& Taylor, 2007). Movement into a position with more responsibility may create prestige and motivate employees to increase their abilities (Parry \& Kelliher, 2009). Such movement can also be used by organizations to attract and retain talent to fill the more senior roles (Heneman, Judge, Smith \& Summers, 2010). Johnston and Lee (2013) found that promotions greatly improve job security, wage perceptions, and generally increase job satisfaction in the short term; however, they found that mental health may be negatively affected after two years in the position. They also found that the positive impacts 
of the promotion were absent after three years and job satisfaction returned to the pre-promotion state with managers feeling the impact of high stress and long work hours. This three-year life span of positive feelings may explain the high mobility career pattern often seen in the hotel industry with applications for job promotions or relocation to a different property occurring as often as every two years. Research (Ladkin and Riley, 1996; Ladkin \& Juwaheer, 2000) revealed that typical hotel general managers change jobs every two to three years. In 2002, Ladkin found that career mobility was a major career strategy and managers held an average of 6.8 jobs in their progression to hotel manager with the same typical job change occurring every two to three years. Research on food and beverage directors working within the hotel industry found "the average length of tenure in these appointments (including present appointment) was 26 months" (Obrien, 2014, p. 10) and the majority worked in more than three different cities. The desire to feel the "promotion high" (the after promotion good feeling phase), may assist in driving this mobility as a form of intrinsic motivation.

In this research, career theory, generational differences working motivations have been combined to explore their impact on influencing a person's intent to apply for a promotion in the hotel industry. Will generational characteristics, working conditions or intrinsic or extrinsic rewards be responsible for employees' decisions to advance their career?

\subsection{Research Questions}

The following questions were created from the literature review to guide this study. The questions are designed to identify those working conditions in the hotel industry that impact employees' perceptions and may affect their wish to apply for a promotion in the industry. Working conditions include level of responsibility, training opportunities, friendliness of the working environment, and others as described in this research. Identifying those conditions that have the greatest impact and if they differ based on demographics would assist managers and human resource directors to develop promotional ladders within their organizations. Providing and encouraging talent into higher positions could impact retention and enable the organization to optimize their talent base.

RQ1: What working conditions are perceived to have the greatest impact on the decision to apply for promotion in the hotel industry?

RQ2: What working conditions are perceived to have the least impact on the decision to apply for promotion in the hotel industry?

RQ3: What working conditions are perceived to be neutral in their impact on the decision to apply for promotion in the hotel industry?

RQ4: Do employees' perceptions of the impact of various working conditions in the promotion decision differ statistically based on their demographic characteristics?

\section{Method}

A survey was created from the literature review. The researchers' primary interest was the tourism industry in Atlantic Canada. The largest city in Atlantic Canada was chosen to conduct this 
exploratory study of hotel employees. An invitation to complete the survey was sent via email to hotel General Managers and Human Resource Managers, who were asked to share it with their employees. An online survey was then emailed to employees who agreed to participate. Consideration for adverse events as a result of completing the survey was considered at the point of Ethics Clearance for this study. The results were kept confidential: no one knew who participated and who did not. Managers were not told who participated in the study for their workplace. The research was considered to be minimal risk, thereby not exposing participants to greater risk than they faced in everyday life.

The survey consisted of both quantitative and qualitative questions designed to probe employees' perceptions of the relevance of 21 working conditions when considering the promotion decision. The working conditions and rating scales were derived from instruments used by Richardson (2009) when he researched career factors and Kusluvan and Kusluvan (2000) in researching attitudes of undergraduate tourism students. Richardson (2009) created a survey to have undergraduates in tourism and hospitality programs rate career factors they felt would be offered in a career in tourism and hospitality. Kusluyan and Kusluyan (2000) used dimensions on the nature of work in the tourism industry with a scale of Strongly agree, Agree, Disagree or Strongly disagree. In this study, respondents were asked to indicate whether or not they felt that the working conditions would influence their decision to pursue a promotion and if so, would the impact be strong or not? Respondents included individuals who had applied for management positions and those who had not. Each working condition was measured on a five-point Likert-type scale ranging from 1) No impact to 5) Strong impact. Each scale had a neutral rating of 3). This rating scale was derived from the instrument used by Clark (2016, p. 103) in researching career success and used the scale of Very satisfied with career progress (5), Somewhat satisfied with career progress (4), Neutral (3), Somewhat dissatisfied with career progress (2) and Very dissatisfied with career progress (1). Demographic questions were asked to better classify and understand the respondents. Demographic questions included gender, age, educational level, marital status, and family size. Career-related questions were also asked including whether they were working at a managerial or non-managerial level and how long they had been working in their current position.

SPSS software was used to analyze frequencies for demographic and career-related characteristics and descriptive statistics to explore the ratings for the working conditions. One-sample t-tests were used determine which of the ratings for the working conditions differed significantly from the neutral scale point (3). Those that were statistically significantly higher than the neutral measure (3) was classified as working conditions with the greatest impact on promotion decisions, while those that were statistically significantly lower than the neutral measure were classified as working conditions with the least impact on the promotion decision. Working conditions with average ratings that were not significantly different from (3) were classified as neutral. The distance between the neutral rating (3) and the observed scale average for each working condition was determined used significance tests. Working conditions with average ratings that were not statistically different from neutral (3) were considered to be neutral ratings. Those with average ratings that were significantly different from neutral (3), and that exceeded 3, were considered to be of greater impact in the promotion decision, while those that 
were significantly different from neutral (3) and that were lower than 3 , were considered to be of little impact in the promotion decision.

Independent samples t-tests and analysis of variance (ANOVA) were used to determine whether there were statistically significant differences between ratings of working conditions based on demographic or career-related characteristics. T-tests for unequal variances were used instead of t-tests for equal variances when a Levene test revealed significant differences between variances (Green \& Salkind, 2003; McDonald, 2014). For ANOVA, the Levene test was used to ensure that there was not a violation of the homogeneity of variance assumption. In the event that variances were significantly different, the Brown-Forysth Robust Test was used instead of ANOVA. The Bonferroni post-hoc test was used to identify statistically significant differences between means as a follow-up to ANOVA or Brown-Forsyth for factors with more than two groups. Correlation analysis was used to analyze significant associations between ratings of working conditions and employees' years in their work position and their number of children.

The Kolgomorov-Smirnov test was used to explore variable distributions, the results of which revealed some differentiation from normality. While sample sizes of 30 or more are typically robust to violations of normality for t-tests and ANOVA (Green \& Salkind, 2003; McDonald, 2014) all of the parametric analyses conducted in this study were further validated by using non-parametric tests to confirm the results. The Wilcoxon Signed Rank test was used as a backup test to ensure validity of one-sample t-tests, while Mann-Whitney U was used to validate Independent Samples t-tests and Kruskall-Wallis Chi-Square wase used to validate results for ANOVA. The results of the nonparametric analyses confirmed results across all parametric tests, thereby validating the results of the analyses and enabling the researchers to report differences in mean ratings, which are easier to visualize and understand than reporting non-parametric results. Spearman's Correlation was as the correlation measure instead of the more commonly used Pearson Correlation to better accommodate non-normally distributed data.

\section{Results}

\subsection{Respondents}

A total of 55 respondents completed the survey: 34 women and 21 men consisting of 30 managers/supervisors and 25 non-managerial employees. While all hotel employees were eligible to complete the survey, the actual population of employees invited to participate is not known because individual properties could opt out and not share the email invitation with their employees. Also, the survey was completely confidential, so the employers of respondents was not collected. The sample is exploratory in nature and not conclusive, in keeping with the goals of this quantitative research study. Sixty percent had completed a university degree. The largest age group were those between the age of 25 and 34 years of age at $32.7 \%$, followed by 35 to 44 at $25.5 \%$. Seventy-eight percent of respondents were between the ages of 25 and 54 and the majority of respondents had been in their position for one to five years $(58.2 \%)$. Less than $10 \%$ of those surveyed had been in their position for more than 10 years. The average time in their current position was five years. Most 


\section{Macrothink}

International Journal of Human Resource Studies

ISSN 2162-3058

2021, Vol. 11, No. 2

respondents were single $(58.2 \%)$ and the majority did not have children $(68.1 \%)$. Twenty-two-parent families had children, compared to two divorced/separated and four single parents. Of the four singles, three had one child and one had two. The separated/divorced parents had two children each. See Table 1 for demographic details.

Table 1. Demographic characteristics of participants

\begin{tabular}{|c|c|c|}
\hline Characteristics & Number & Percent \\
\hline \multicolumn{3}{|l|}{ Gender } \\
\hline Men & 21 & 38.2 \\
\hline Women & 34 & 61.8 \\
\hline Total & 55 & 100.0 \\
\hline \multicolumn{3}{|l|}{ Age } \\
\hline 18 to 24 & 10 & 18.2 \\
\hline 25 to 34 & 18 & 32.7 \\
\hline 35 to 44 & 14 & 25.5 \\
\hline 45 to 54 & 11 & 20.0 \\
\hline 55 to 64 & 1 & 1.8 \\
\hline 65 and Over & 1 & 1.8 \\
\hline Total & 55 & 100.0 \\
\hline \multicolumn{3}{|l|}{ Education } \\
\hline Less than Grade 12 & 2 & 3.6 \\
\hline High school & 4 & 7.3 \\
\hline Some college & 16 & 29.1 \\
\hline Bachelor's degree & 33 & 60.0 \\
\hline Total & 55 & 100.0 \\
\hline \multicolumn{3}{|l|}{ Marital Status } \\
\hline Single & 32 & 58.2 \\
\hline Married & 21 & 38.2 \\
\hline Divorced/Separated & 2 & 3.6 \\
\hline Total & 55 & 100.0 \\
\hline \multicolumn{3}{|l|}{ Number of Children } \\
\hline None & 34 & 61.8 \\
\hline One child & 7 & 12.7 \\
\hline Two children & 11 & 20.0 \\
\hline Three or more children & 2 & 3.6 \\
\hline Total & 55 & 100.0 \\
\hline \multicolumn{3}{|c|}{$\begin{array}{l}\text { Range: } 0 \text { to } 5 \text {; Average }<1 \text { child, Std Deviation }<1 \\
\text { child }\end{array}$} \\
\hline \multicolumn{3}{|l|}{ Single Parenthood } \\
\hline Single - One child & 1 & 1.8 \\
\hline Single - Two children & 3 & 5.5 \\
\hline Divorced/Separated - One child & 0 & 0.0 \\
\hline
\end{tabular}




\begin{tabular}{lll}
\hline Divorced/Separated - Two children & 2 & 3.6 \\
\hline Not applicable (not single parents) & 49 & 89.1 \\
\hline Total & 6 & 100.0 \\
\hline Level of Current Position & & \\
\hline Non-managerial & 25 & 45.5 \\
\hline Managerial/supervisory & 30 & 54.5 \\
\hline Total & 55 & 100.0 \\
\hline Time in Current Position & & \\
\hline Less than a year & 5 & 9.1 \\
\hline 1 to 5 years & 32 & 58.2 \\
\hline 6 to 10 years & 10 & 18.2 \\
\hline 11 to 15 years & 4 & 7.3 \\
\hline 16 to 20 years & 3 & 5.5 \\
\hline 20 to 25 years & 1 & 1.8 \\
\hline Total & 55 & 100.0 \\
\hline
\end{tabular}

Range: < 1 year to 22 years;

Average $=5.1$ years,

Std Deviation $=5.3$ years

\subsection{Perceptions of Working Conditions}

Respondents were asked to rate 21 working condition statements based on the impact that each would have on their decision to apply for promotion. Each of the statements was rated on a five-point Likert-type scale: 5) Strong impact 4) Some impact 3) Neutral 2) Little impact 1) No impact. Twelve of the working conditions had average scale ratings significantly higher than the neutral (3) rating. The average ratings for each of these highly rated working conditions ranged from 3.51 to 4.51 on the five-point rating scale. Each of these strong promotion influencers focused on tasks that enriched the employee's job, reflecting higher levels of responsibility and the ability to learn new things and to make positive change in the organization. The 12 most highly rated working conditions impacting the promotion decision are shown in Table 2.

Table 2. Working conditions perceived as having the greatest impact on the promotion decision (Rated significantly higher than neutral)

\begin{tabular}{llll}
\hline $\begin{array}{l}\text { Working Condition } \\
\text { (N=55) }\end{array}$ & Range & Average & $\begin{array}{l}\text { Std. } \\
\text { Deviation }\end{array}$ \\
\hline Having the empowerment to make changes & 2 to 5 & 4.51 & .71 \\
\hline $\begin{array}{l}\text { Having the ability to impact guests in a positive } \\
\text { way }\end{array}$ & 1 to 5 & 4.49 & .77 \\
\hline $\begin{array}{l}\text { Receiving an increased salary with potential } \\
\text { bonus }\end{array}$ & 1 to 5 & 4.47 & .81 \\
\hline $\begin{array}{l}\text { Receiving cross-training - learning new } \\
\text { techniques }\end{array}$ & 3 to 5 & 4.44 & .71 \\
\hline \begin{tabular}{l} 
Working in a friendly environment \\
\hline
\end{tabular} & 1 to 5 & 4.44 & .79 \\
\hline
\end{tabular}




\begin{tabular}{llll}
\hline Working with a team of the hotel & 2 to 5 & 4.35 & .80 \\
\hline $\begin{array}{l}\text { Having job perks, such as cheap food, travel } \\
\text { benefits and training }\end{array}$ & 3 to 5 & 4.31 & .74 \\
\hline Using my ability to be creative & 2 to 5 & 4.25 & .84 \\
\hline Taking on more responsibility and new job tasks & 1 to 5 & 4.09 & 1.02 \\
\hline Creating work schedules & 1 to 5 & 3.53 & .90 \\
\hline Conducting employee evaluations & 1 to 5 & 3.51 & .90 \\
\hline $\begin{array}{l}\text { Having a flexible work schedule during low } \\
\text { season }\end{array}$ & 2 to 5 & 4.04 & .86 \\
\hline $\begin{array}{l}\text { *Sample size = 55. Rating scale: 5) Strong impact 4) Some impact 3) Neutral 2) } \\
\text { Little impact 1) No impact. }\end{array}$ & \\
\hline
\end{tabular}

\subsection{Significant Differences in Perceptions of Working Conditions}

Seven of the 21 working conditions differed significantly from the neutral rating (3) and had lower ratings indicating less impacts on the promotion decision. Qualitatively each of these working conditions reflected the downside of working in the hospitality industry, with long hours and a lot of overtime, particularly during peak tourism season. The expectation that working longer hours would have impacts on the personal lives of managers was also noted in this group of working conditions. However, the ratings also indicate that employees did not believe that these working conditions impacted their promotion decision. These working conditions are shown in Table 3.

Table 3. Working conditions as having least impact on the promotion decision (Rated significantly lower than neutral)*

\begin{tabular}{|c|c|c|c|}
\hline $\begin{array}{l}\text { Working Condition } \\
(\mathrm{N}=55)\end{array}$ & Range & Average & $\begin{array}{l}\text { Std. } \\
\text { Deviation }\end{array}$ \\
\hline $\begin{array}{l}\text { Having a lack of involvement with family } \\
\text { activities due to long hours }\end{array}$ & 1 to 4 & 2.00 & .84 \\
\hline $\begin{array}{l}\text { Having a lack of social life due to long } \\
\text { hours }\end{array}$ & 1 to 4 & 2.05 & .85 \\
\hline $\begin{array}{l}\text { Having a lack of vacation in the busy } \\
\text { season }\end{array}$ & 1 to 5 & 2.38 & .85 \\
\hline Working longer hours & 1 to 5 & 2.45 & .79 \\
\hline Working late hours during high season & 1 to 5 & 2.51 & .77 \\
\hline Dealing with staff calling in sick & 1 to 5 & 2.56 & .81 \\
\hline Having to work overtime & 1 to 5 & 2.73 & .78 \\
\hline \multicolumn{4}{|c|}{$\begin{array}{l}\text { *Sample size }=55 . \text { Rating scale: 1) No impact 2) Little impact 3) Neutral 4) } \\
\text { Some impact 5) Strong impact. }\end{array}$} \\
\hline
\end{tabular}

The remaining two working conditions studied did not differ from the neutral rating (3) and were classified as being neutral and having no real influence on the promotion decision. These two working conditions that had no impact when considering the promotion decision reflected regular job tasks that come with those working in the hotel sector: tasks related to 
managing human resources and meeting customer needs. Given that these are regular aspects of the job they may not be relevant when considering whether to apply for a promotion. These neutral working conditions are shown in Table 4.

Table 4. Working conditions perceived as neutral in the promotion decision*

\begin{tabular}{llll}
\hline $\begin{array}{l}\text { Working Condition } \\
(\mathrm{N}=55)\end{array}$ & Range & Average & $\begin{array}{l}\text { Std. } \\
\text { Deviation }\end{array}$ \\
\hline $\begin{array}{l}\text { Having to discipline } \\
\text { employees }\end{array}$ & 1 to 5 & 3.09 & .80 \\
\hline $\begin{array}{l}\text { Dealing with demanding } \\
\text { guests }\end{array}$ & 1 to 5 & 3.07 & .88 \\
\hline $\begin{array}{l}\text { *Sample size = 55. Rating scale: 5) Strong impact 4) Some impact 3) Neutral } \\
\text { 2) Little impact, 1) No impact. }\end{array}$ & \\
\hline
\end{tabular}

\subsection{Personal Characteristics and Perceptions of Working Conditions}

Further analysis was conducted to explore the possible association between personal characteristics and the impact of working conditions on the promotion decision. The results showed no statistically significant differences between impact ratings of working conditions based on gender or number of children or the length of time in their current position, where none of the correlations were statistically significant for any of the working conditions. However, there were statistically significant differences based on age, marital status, and education as in Table 5.

ANOVA showed statistically significant differences between age and the working condition of receiving an increased salary with a potential bonus $(\mathrm{F}=3.992(1,53), \mathrm{p}=.013)$. Those under the age of 45 rated "receiving an increased salary with potential bonus" as having some impact/strong impact on the promotion decision with average scale ratings ranging from 4.60 to 4.72. Those aged 45 and older rated it as less impactful or neutral with an average scale rating of 3.85, which was significantly different from the average rating for those in the 25 to 34 age range. This could reflect the fact that as employees age financial incentives may be less of a motivator. There were no statistically significant differences for age 18 to 24 or 35 to 44.

There were statistically significant differences for ANOVA for the working condition "conducting employee evaluations" based on education level $(\mathrm{F}=4.866(1,53), \mathrm{p}=.012)$. Those with a bachelor's degree rated this working condition as higher than those with some college. Those with a bachelor's degree had an average scale rating of 3.79 for this working condition compared to average of 3.00 for those with some college. This indicates that those with university educations were more likely to see conducting employee evaluations as more influential in a promotion decision than were those with some college. There were no significant differences among those with a high school education or less.

Table 5. ANOVA results for statistically significant differences in ratings for working conditions by demographic characteristics of employees 


\begin{tabular}{|c|c|c|c|}
\hline Working Condition & Demographic & Average & $\begin{array}{l}\text { Std. } \\
\text { Deviation }\end{array}$ \\
\hline \multirow{4}{*}{$\begin{array}{l}\text { Conducting } \\
\text { evaluations }\end{array}$} & \multicolumn{3}{|l|}{ Education: } \\
\hline & Up to Grade $12(n=6)$ & 3.33 & 1.033 \\
\hline & Some college $(\mathrm{n}=16)^{* *}$ & 3.00 & 1.033 \\
\hline & Bachelor's degree $(n=33) * *$ & 3.79 & .696 \\
\hline \multirow{9}{*}{$\begin{array}{l}\text { Receiving an increased salary } \\
\text { with potential bonus }\end{array}$} & \multicolumn{3}{|l|}{ Age: } \\
\hline & 18 to $24(n=10)$ & 4.60 & .516 \\
\hline & 25 to $34(\mathrm{n}=18)^{* *}$ & 4.72 & .461 \\
\hline & 35 to $44(n=14)$ & 4.64 & .633 \\
\hline & 45 and Over $(n=13) * *$ & 3.85 & 1.214 \\
\hline & \multicolumn{3}{|l|}{ Marital Status: } \\
\hline & Single $(n=32)$ & 4.44 & .840 \\
\hline & Married $(n=21)$ & 4.67 & .658 \\
\hline & $\begin{array}{l}\text { Separated/Divorced/Widowed } \\
(\mathrm{n}=2)^{* *}\end{array}$ & 3.00 & .000 \\
\hline \multirow{4}{*}{$\begin{array}{l}\text { Having the empowerment to } \\
\text { make changes }\end{array}$} & \multicolumn{3}{|l|}{ Marital Status: } \\
\hline & Single $(\mathrm{n}=32)$ & 4.44 & .619 \\
\hline & Married $(n=21)$ & 4.71 & .561 \\
\hline & $\begin{array}{l}\text { Separated/Divorced/Widowed } \\
(\mathrm{n}=2)^{* *}\end{array}$ & 3.50 & .707 \\
\hline \multirow{4}{*}{$\begin{array}{l}\text { Having a flexible work } \\
\text { schedule during low season }\end{array}$} & \multicolumn{3}{|l|}{ Marital Status: } \\
\hline & Single $(n=32)$ & 3.84 & .847 \\
\hline & Married $(\mathrm{n}=21)^{* *}$ & 4.43 & .746 \\
\hline & $\begin{array}{l}\text { Separated/Divorced/Widowed } \\
(\mathrm{n}=2)^{* *}\end{array}$ & 3.00 & .000 \\
\hline
\end{tabular}

ANOVA revealed statistically significant differences between three of the working condition ratings and marital status. These working conditions included having a flexible work schedule during low season $(\mathrm{F}=5.117(1,53), \mathrm{p}=.009)$, receiving an increased salary with potential bonus $(\mathrm{F}=4.399(1,53), \mathrm{p}=.017)$ and having the empowerment to make changes $(\mathrm{F}=3.252(1,53), \mathrm{p}=.047)$. In all three tests the results showed that those who were divorced or separated rated the working condition as more neutral than the other group(s). For flexible working schedule during low season the separated and divorced employees had an average scale rating of 3.00, differing significantly from those who were married and had an average scale rating of 4.43. This demonstrated that among married employees having a flexible schedule during low season was a fairly strong influence when considering a promotion. The average rating of single employees for this working condition $(\mathrm{M}=3.84)$ did not differ significantly from either the married or separated/widowed employees. Average ratings of single and married employees for the other two working conditions were not significantly different from each other, but they both differed significantly from those who were separated 
or divorced. Receiving an increased salary with potential bonus was rated as a rather strong positive influence on the promotion decision by single $(M=4.44)$ and married $(M=4.67)$ employees. Separated/divorced employees had a scale average of 3.00, indicating neutrality. For the working condition "having the empowerment to make changes" single employees had an average scale rating of 4.44, while married employees had an average scale rating of 4.71. Separated/divorced employees had a scale rating of 3.5, which was close to neutrality.

\subsection{Management Experience and Working Conditions}

There were statistically significant differences for four of the working conditions and their impact on the promotion decision based on whether respondents were currently in managerial/supervisory or non-managerial positions. Average ratings were higher for those in managerial/supervisory positions than for those in non-managerial positions. The average rating for "having the empowerment to make changes" was 4.77 on the five-point scale for those in managerial/supervisory positions compared to 4.20 for those in non-managerial positions $(\mathrm{t}=-2.980(33.705), \mathrm{p}=.005)$.

Table 6 Statistically significant differences from Independent samples T-Test for average impact ratings or working conditions on the promotion decision by position in firm*

\begin{tabular}{|c|c|c|c|}
\hline Working Condition & $\begin{array}{l}\text { Managerial/Non-Managerial } \\
\text { Position in Firm }\end{array}$ & Average & $\begin{array}{l}\text { Std. } \\
\text { Deviation }\end{array}$ \\
\hline \multirow{2}{*}{$\begin{array}{l}\text { Conducting employee } \\
\text { evaluations }\end{array}$} & Non-Managerial** & 3.16 & .943 \\
\hline & Managerial** & 3.80 & .761 \\
\hline \multirow{2}{*}{$\begin{array}{l}\text { Having the empowerment to } \\
\text { make changes }\end{array}$} & Non-Managerial** & 4.20 & .866 \\
\hline & Managerial $* *$ & 4.77 & .430 \\
\hline \multirow{2}{*}{$\begin{array}{l}\text { Taking on more responsibility } \\
\text { and new job tasks }\end{array}$} & Non-Managerial** & 3.76 & 1.165 \\
\hline & Managerial** & 4.37 & .809 \\
\hline \multirow{2}{*}{$\begin{array}{l}\text { Having to discipline } \\
\text { employees }\end{array}$} & Non-Managerial** & 2.84 & .800 \\
\hline & Managerial** & 3.30 & .750 \\
\hline
\end{tabular}

*Samples: Non-Managerial (25) Managerial (30). Rating scale: Rating scale: 5) Strong impact 4) Some impact 3) Neutral 2) Little impact 1) No impact. ** Means significantly different from each other.

The working condition, "conducting employee evaluations" was rated 3.80 by managerial/supervisory level respondents, compared to an average of 3.16 for non-managerial workers $(\mathrm{t}=2.785(53), \mathrm{p}=.007)$. Managerial/supervisory respondents rated "taking on more responsibility and new job tasks" 4.37 compared to an average rating or 3.76 for non-managerial respondents $(\mathrm{t}=-2.272$ (53), $\mathrm{p}=.027)$. Finally, managerial/supervisory employees rated "having to discipline employees" at 3.30, compared to an average rating of 2.84 for non-managerial employees $(\mathrm{t}=-2.198(53), \mathrm{p}=.032)$. The results are summarized in Table 6.

\section{Discussion}

The first research question was to identify the working conditions that had the greatest impact on the decision to apply for a promotion as perceived by hotel employees. Ten working 
conditions were highly rated as being impactful and the top three include: having the empowerment to make changes $(\mathrm{M}=4.51, \mathrm{SD}=.71)$; having the ability to impact guests in a positive way $(\mathrm{M}=4.49, \mathrm{SD}=.77)$, and receiving an increased salary with potential bonus (M $=4.47, \mathrm{SD}=.81)$. The first two working conditions could be considered intrinsic in nature with the desire to have control and to make an impact. This certainly agrees with research on personality and intrinsic rewards. Walsh \& Taylor (2007) found that intrinsic motivators were more important, and hospitality graduates in their study rated challenging work and learning-oriented relationships with their managers very highly when asked what they were looking for in their careers. If it is intrinsic motivators that encourage employees then it would be important for human resources and management to ensure the job postings include such conditions and descriptions.

As $49.9 \%$ respondents were in the age group of 18 to 34 , it appears that they fall into the Millennial category and as such, could explain why the highest rated working conditions that positively impacted promotion decisions were having the empowerment to make changes $(\mathrm{M}=4.51, \mathrm{SD}=.71)$, having the ability to impact guests in a positive way $(\mathrm{M}=4.49, \mathrm{SD}=.77)$, and receiving an increased salary with potential bonus $(\mathrm{M}=4.47, \mathrm{SD}=.81)$. This agrees with the Deloitte research (2019) on Millennials that found they are attracted to working conditions where they can work in their own manner and have empowerment and impact in their position.

In answering the second research question, seven working conditions were rated as having little to no influence on the promotion decision. The three less impactful working conditions rated were: having a lack of involvement with family activities due to long hours $(\mathrm{M}=2.00$, $\mathrm{SD} .84)$; having a lack of social life due to long hours $(\mathrm{M}=2.05, \mathrm{SD}=.85)$, and having a lack of vacation in the busy season $(\mathrm{M}=2.38, \mathrm{SD}=.85)$. Working long hours can be a major negative working condition for the hotel industry as part of its long operating hours. Also dealing with staff shortages or when staff call in as sick can lead to many challenging situations. Front line employees may be seeing the supervisory role as unattractive. It is the first promotion from online employee to supervisor that may be the most difficult step as the job may not be seen in light of the benefits it can create, including leading to the next promotion along a linear career path. Despite the negative nature of these working conditions, employees did not perceive them as impacting the promotion decision. Essentially, it appears that employees are well acquainted with the challenges of working in the hospitality sector and they seemed prepared to make sacrifices as required to facilitate moving up the career ladder.

The third research question was to identify those working conditions that were neutral in the decision to apply for a promotion. The two working conditions were: having to discipline employees $(\mathrm{M}=3.09, \mathrm{SD}=.80)$ and dealing with demanding guests $(\mathrm{M}=3.07, \mathrm{SD}=.88)$. These working conditions are basic supervisor responsibilities and are probably expected but may not be perceived as a pleasurable part of being a manager. However, they were not perceived as having influence or not having influence on the promotion decision.

The fourth research question included further analysis on the possible association between 
personal characteristics and ratings and did indicate that older respondents aged 45 and up, rated the financial incentives as less of a motivator. This may indicate managers with longer tenure and more experience enjoy greater financial stability leading them to looking for other motivators. Also, married employees, who made up 38.2\% of respondents considered flexible schedules to be a more positive motivator when applying for a promotion. This difference may be due to a desire for greater autonomy when considering family responsibilities. However only $36.6 \%$ of the respondents had children and the number of children in the home was not significantly correlated with any of the working conditions.

There were significant differences in ratings based on the respondent's position in the firm, with those in managerial/supervisory positions rating four working conditions more positively than non-managerial respondents. As only $45.5 \%$ of the respondents were in a non-managerial role, it is important to note that these results are a mixture of those in the management roles and those who are only perceiving the management role. Three of the four working conditions were more demanding and possibly more challenging: conducting employee evaluations, disciplining employees, and taking on more responsibilities and new tasks. These may be more challenging for non-managerial workers than for those with managerial/supervisory experience. The fourth working condition, having the empowerment to make changes, was not necessarily challenging, but it may require more creativity and employee engagement. It is reasonable to expect that employees with managerial experience would be more comfortable taking on greater responsibility or handling more challenging tasks. The length of time one was in their current position was not significantly correlated with any of the working conditions. This indicates that seniority did not seem to influence the perception.

These findings are important to the hotel industry as they can assist in encouraging employees to apply for promotions or job postings that can lead to further career steps. Keeping talented employees and managers would lead to a more efficient and successful business especially in a labor shortage situation. When job postings are created, they should include important working conditions such as identified here; information on how the position gives empowerment to make changes within the department, the ability to impact guests in a positive manner and highlight the creative areas of the job such as the ability to form solutions or better procedures or products. Also describing how the team works would also allay any fears of working with a group of people that may not be team orientated. Any future training opportunities should be outlined and work schedules that allow for a life outside of the company such as flexible schedules or working at home options should be described. The benefits of vacation pay and travel within the company with employee discounts can also make the job more attractive.

Managers and executives can encourage those employees they deem as potential candidates by verbally asking them to apply and then give their names to the recruiting team, thereby being a sponsor. Some employees who do not think they are ready may need this encouragement from their supervisors.

\section{Conclusion}


The identification of those conditions that have an impact on employees who may consider applying for promotions is critical for the industry. The top three conditions identified as having the greatest impact were: having the empowerment to make changes $(M=4.51, S D$ $=.71)$; having the ability to impact guests in a positive way $(\mathrm{M}=4.49$, SD $=.77)$, and receiving an increased salary with potential bonus $(\mathrm{M}=4.47, \mathrm{SD}=.81)$. This gives insight into the factors that employees consider prior to applying for a promotion and can be used to enhance the application process and increase the number of applicants so managers have a greater number of candidates to consider. An increased number of applicants would give managers more choice and greater success in choosing the correct candidate. The right candidate in the right position would also lead to greater job satisfaction and may increase retention. Also, as $49 \%$ of the respondents were Millennials the opportunity to take advantage of this large demographic labor pool can be done if these impact factors are used to attract them to the industry and to develop a career in the industry. Also identifying those factors that had little or neutral impact is important as these factors allow hotel recruiters can focus on the factors that do impact such career decisions.

\section{Limitations and Delimitations}

This research contributes to the greater understanding of the motivations of hotel employee and career development, but more research is needed. This research was limited by a small sample size. A larger sample with a broader demographic profile would be helpful to better understand how age, marital status, and education impact promotion decisions. Future research should also focus on years of experience in the workplace to better break out managerial and supervisory roles to explore how barriers to promotion may influence employees' initial decision to enter a supervisory position. Future research could also focus more on the qualitative nature of working conditions and how employees rationalize difficult work environments and challenging working conditions as they aspire to higher levels of management in their organizations.

\section{Summary}

This research revealed that the promotion decision among hotel employees is impacted by several perceived working conditions, some of which relate to the nature of the job and others that focus on work-life balance and career demands. There were no statistically significant differences based on gender, which was an important result given that most organizations are encouraging more women to strive for managerial positions. There were some differences based on age, marital status, and education. However, for most of the perceived working conditions there were no statistically significant differences based on demographic profile.

The position of the respondent in the firm had some impact with four out of twenty-one working conditions differing significantly based on managerial/non-managerial work experience. It is not unexpected that less experienced employees would be circumspect when considering promotions leading to greater responsibility, particularly where evaluating, and disciplining other workers may be involved.

This research also revealed that most of the working conditions that were perceived by 
employees to have some or strong impact on the promotion decision were positive and motivational kinds of working conditions. Also, working conditions endemic to the industry that were challenging and could negatively impact employees' quality of life were not perceived to impact the promotion decision.

\section{References}

Akrivos, C., Ladkin, A., \& Reklitis, P. (2007). Hotel managers' career strategies for success. International Journal of Contemporary Hospitality Management, 19(02), 107-119. https://doi.org/10.1108/09596110710729229

Blayney, C., \& Blotnicky, K. (2014). Career development of Canadian hotel managers in the hospitality industry: An examination of gender perceptions of barriers and facilitators in career advancement. Journal of Management and World Business Research, 11(01), 1-11.

Blayney, C., \& Blotnicky, K. (2016). Career strategies of hotel managers in Canada. Global Journal of Business Research, 10(02), 33-48.

Brown, E. (2011). Hospitality management graduates' perceptions of career factor importance and career factor experience and the relation with turnover intentions. Graduate Theses and Dissertations. Paper 12001. Found October 2019 at https://lib.dr.iastate.edu/etd/12001/

Clark, R. (2016). Grit within the context of career success: A mixed methods study. International Journal of Applied Positive Psychology, 4, 91-111. https://doi.org/10.1007/s41042-019-00020-9

Cocolakis-Wormstall, M. (2018). Labour shortage: Here to stay. Worker scarcity in Canada and what businesses can do to respond. Business Development Bank of Canada found October 2019 at https://www.bdc.ca/en/documents/analysis_research/labour-shortage.pdf

Crawshaw, J., \& Game, A. (2015). The role of line managers in employee career management: An attachment theory perspective. The International Journal of Human resource Management, 26(09), 1182-1203.

Deloitte. (2019). The Deloitte global millennial survey 2019: Societal discord and technological transformation create a "generation disrupted". Found October 2019 at https://www2.deloitte.com/global/en/pages/about-deloitte/articles/Millennialsurvey.html\#vide o

Dimock, M. (2019). Defining generations: Where millennials end and generation Z begins. Pew Research found October 2019 at http://tony-silva.com/eslefl/miscstudent/downloadpagearticles/defgenerations-pew.pdf

Garavan, R., O’Brien, F., \& O'Hanlan, D. (2006). Career advancement of hotel managers since graduation: A comparative study. Personnel Review, 35(03). 252-280. https://doi.org/10.1108/00483480610656685

Ghebregiorgis, R. (2018). Factors influencing employee performance in hotel-A comparative study of government and privately owned hotels in Eritrea. International Journal of Research 
in Business Studies and Management, 5(11), 01-09.

Green, S. B., \& Salkind, N. J. (2003). Using SPSS for Windows and Macintosh: Analyzing and Understanding Data, 3/e. Prentice-Hall, Upper Saddle River, NJ.

Harper, S., Brown, C., \& Irvine, W. (2005). Qualifications: A fast-track to hotel general manager? International Journal of Contemporary Hospitality Management, 17(01), 51-64. https://doi.org/10.1108/09596110510577671

Heneman, H., Judge, T., Smith, V., \& Summers, R. (2010). Staffing organizations: Recruitment and selection. $2^{\text {nd }}$ Ed. Canada: McGraw-Hill Ryerson.

Johnston, D., \& Lee, W. (2013). Extra status and extra stress: Are promotions good for us? ILR Review, 66(01), 32-54. https://doi.org/10.1177/001979391306600102

Kim, S., Chun, H., \& Petrick, J. (2009). Career path profiles of general managers of Korean super deluxe hotels and factors influencing their career development: Vocational insights for HTM students and hotel employees. Journal of Hospitality, Leisure, Sport \& Tourism Education, 8(02), 97-116. https://doi.org/10.3794/johlste.82.212

Kusluvan, S., \& Kusluvan, Z. (2000). Perceptions and attitudes of undergraduate tourism students towards working in the tourism industry in Turkey. Tourism Management, 21(3), 51-269. https://doi.org/10.1016/S0261-5177(99)00057-6

Ladkin, A. (2002). Career analysis: a case study of hotel general managers in Australia. Tourism Management, 23(04), 379-388. https://doi.org/10.1016/S0261-5177(01)00092-9

Ladkin, A., \& Juwaheer, T. (2000). The career paths of hotel general managers in Mauritius. International Journal of Contemporary Hospitality Management, 12(02), 119-125. https://doi.org/10.1108/09596110010309925

Ladkin, A., \& Riley, M. (1996). Mobility and structure in the career paths of UK hotel managers: a labour market hybrid of the bureaucratic model? Tourism Management, 17(06). 443-452. https://doi.org/10.1016/0261-5177(96)00053-2

McDonald, J. H. (2014). Handbook of Biological Statistics. Retrieved July 27, 2020, from http://www.biostathandbook.com/normality.html

McGinley, S., Hanks, L., \& Line, N. (2017). Constraints to attracting new hotel workers: A study on industrial recruitment. International Journal of Hospitality Management, 60, 114-122. https://doi.org/10.1016/j.ijhm.2016.10.010

McGuire, D., Polla, G., \& Heidl, B. (2017). Unlocking hospitality managers career transitions through applying Schein's career anchors theory. European Journal of Training and Development, 41(07), 578-592. https://doi.org/10.1108/EJTD-04-2016-0022

Morgan, M. (2002). Career-building strategies. Strategic Finance: Montvale, 83(12), 38-473.

Nebel III, E., Lee, J., \& Vidakovic, V. (1995). Hotel general manager career paths in the United Stated. International Journal of Hospitality Management, 14(3-4), 245-260. 
https://doi.org/10.1016/0278-4319(95)00026-7

Obrien, P. (2014). Climbing the hospitality career ladder: Career guidance insights from social networking profiles. Journal of Tourism and Hospitality Management, 2(01). 01-17.

Parry, E., \& Kelliher, C. (2009). Voluntary sector responses to increased resourcing challenges. Employee Relations, 31(01), 9-24. https://doi.org/10.1108/01425450910916797

Putra, E., Cho, S., \& Liu, J. (2017). Extrinsic and intrinsic motivation on work engagement in the hospitality industry: Test of motivation crowding theory. Tourism and Hospitality Research, 17(02), 228-241. https://doi.org/10.1177/1467358415613393

Richardson, S. (2009). Undergraduates' perceptions of tourism and hospitality as a career choice. International Journal of Hospitality Management, 28(3), 382-388. https://doi.org/10.1016/j.ijhm.2008.10.006

Ruddy, J. (1989). Career development of hotel managers in Hong Kong. International $\begin{array}{llll}\text { Journal of Hospitality } & \text { Management, } & \text { 8(03), }\end{array}$ https://doi.org/10.1016/0278-4319(89)90018-2

Schein, E. (1975). How career anchors hold executives to their career paths. Personnel, 52, 11-24.

Swanljung, M. (1981). How hotel executives made the climb to the top. The Cornell Hotel and Administration Quarterly, 22(01), 30-34. https://doi.org/10.1177/001088048102200107

Swe, T., \& Walsh, J. (2016). Factors affecting employees' performance in Mandalay hotel industry. Recent Issues in Human Resource Management, 1(01). 26-61.

U.S Bureau of Labor Statistics (2018). Occupational outlook handbook lodging managers found October 2019 at https://www.bls.gov/ooh/management/lodging-managers.htm

Walsh, K., \& Taylor, M. (2007). Developing in-house careers and retaining management talent. Cornell Hotel and Restaurant Administration Quarterly, 48(02), 163-182. https://doi.org/10.1177/0010880407300521

WTTC, World Tourism \& Travel Council. (2015a). 14 million jobs at risk due to global travel \& tourism talent shortage. Found October 2019 at https://sp.wttc.org/about/media-centre/press-releases/press-releases/2015/14-million-jobs-at-r isk-due-to-global-travel-tourism-talent-shortage/

WTTC, World Travel \& Tourism Council, (2015b). Global talent trends and issues for the travel \& tourism sector. Found October 2019 at https://www.wttc.org/-/media/382bb1e90c374262bc951226a6618201.ashx

Yildirim, B., Gulmez, M., \& Yildirim, F. (2016). The relationship between the five-factor personality traits of workers and their job satisfaction: a study on five star hotels in Alanya. Procedia, Economics and Finance, 39, 284-291.

https://doi.org/10.1016/S2212-5671(16)30325-2 


\section{Appendix}

\section{Demographics}

Gender : Male

Female

Age: $18-24$

$25-34-35-44$

$45-54$

$55-64$

65 and over

What is your job title?

How long have you been in your current position?

(number of years)

Indicate the level of education attained below

High School

Bachelors

Master

$\mathrm{PhD}$

What is your marital status?

Single ___ Married

Divorced Separated

Widowed

Number of children

\section{Working Condition Statements}

On a scale of one (1) to five (5) with 5 indicating a strong impact and 1 indicating no impact, please indicate whether or not the following statements would affect your decision to apply for a supervisory or management position
(5) Strong impact
(4) Some impact
(3) Neutral
(2) Little impact (1) no impact

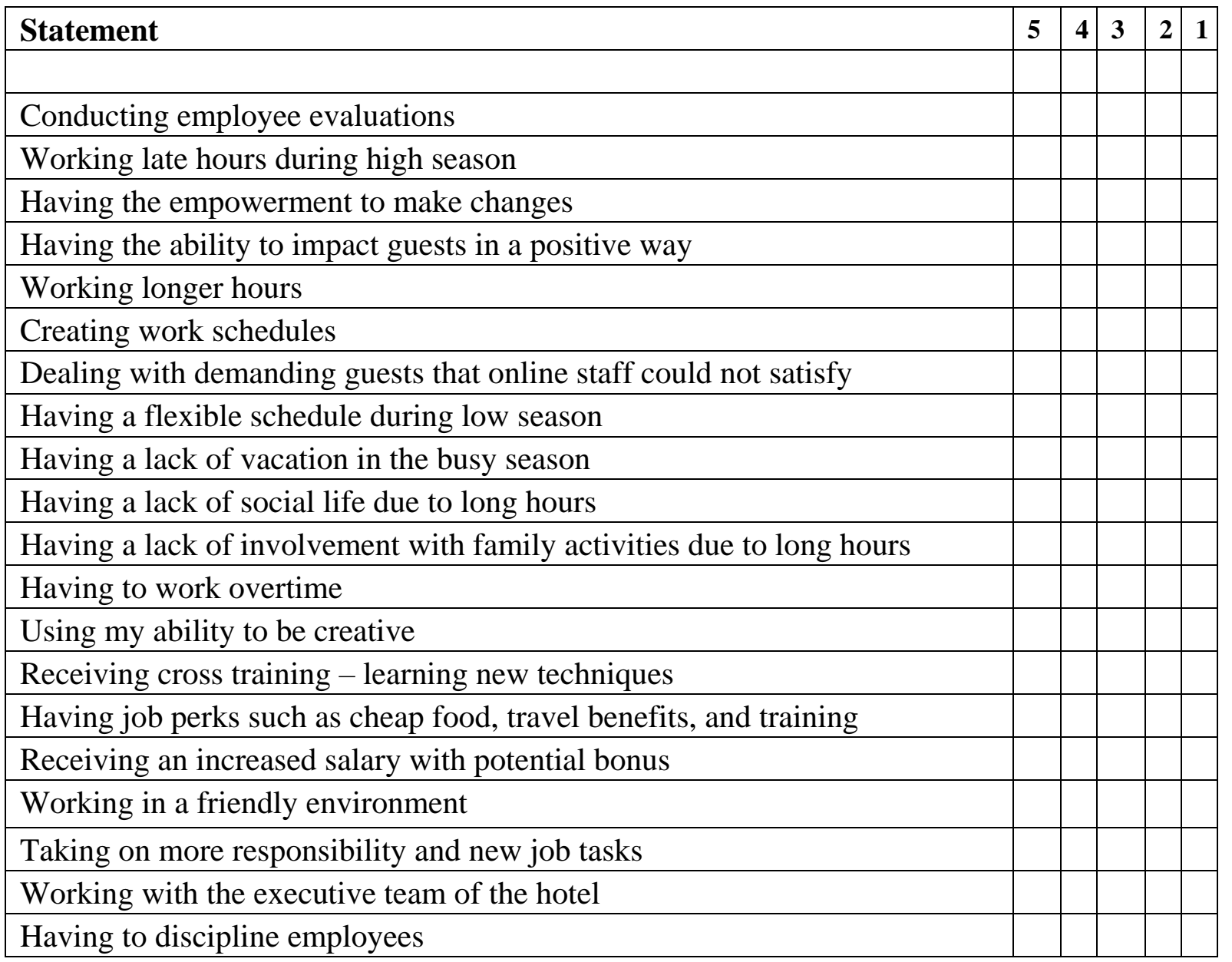


Dealing with staff calling in sick

\section{Copyright Disclaimer}

Copyright for this article is retained by the author(s), with first publication rights granted to the journal.

This is an open-access article distributed under the terms and conditions of the Creative Commons Attribution license (http://creativecommons.org/licenses/by/4.0/). 